\title{
ВІДТВОРЮВАЛЬНА ЗДАТНІСТЬ КОРІВ ТА ЇХ ПОТОМКІВ РІЗНИХ ГЕНЕРАЦІЙ
}

Федорович Єлизавета Іллівна

доктор сільськогосподарських наук, професор Інститут біології тварин НААН України ORCID: https://orcid.org/0000-0002-9910-7902 E-mail: logir@ukr.net

Федорович Віталій Васильович доктор сільськогосподарських наук, старший науковий співробітник Інститут розведення і генетики тварин імені М. В. Зубця НААН України ORCID: https://orcid.org/0000-0002-4272-4045 E-mail: lionel@i.ua

Мазур Наталія Петрівна доктор сільськогосподарських наук Інститут біології тварин НААН України ORCID: http://orcid.org/0000-0001-6244-713X

E-mail: Babikn@i.ua

Боднар Петро Васильович кандидат сільськогосподарських наук Львівський національний університет ветеринарної медицини та біотехнологій імені С. 3. Гжицького ORCID: https://orcid.org/0000-0002-5103-2593 E-mail: bodnarlviv28@ukr.net

Филь Сергій Іванович аспірант Інститут розведення і генетики тварин імені М. В. Зубця НААН України ORCID: https://orcid.org/0000-0002-5060-1889

Email: fyl@avm-ua.org

Останнім часом у літературних джерелах все частіше з'являються повідомлення про те, що показники відтворювальної здатності тварин зумовлюються генетичними чинниками, такими як належність до породи, типу, генотипу, ліній, походженням за батьком, методу підбору тощо. Однак, на даний час недостатньо вивчено вплив матерів на показники відтворювальної здатності їх потомків різних поколінь. 3 огляду на зазначене метою наших досліджень було вивчити відтворювальну здатність корів та їх потомків різних генерацій у високопродуктивних стадах (середній надій на корову близько 10000 ке). Дослідження проведені на коровах стад ТОВ «Велетень» Сумської області та ПАТ «Племзавод “Стєпной"» Запорізької області, створених за поглинального схрещування маток української чорно-рябої молочної породи з голштинськими плідниками. На основі ретроспективного аналізу даних зоотехнічного обліку (програма управління молочним стадом «Юніформ-Агрі»), та результатів власних досліджень у корів, отелення яких відбулося у період з 2004 nо 2017 рр., вивчали: вік та живу масу при першому плідному осіменінні й першому отеленні, тривалість тільності, періоду від отелення до першого осіменіння (індепенденс-період), сервіс-, сухостійного та міжотельного періодів, коефріцієнт відтворювальної здатності, вихід телят на 100 корів, індекс осіменіння та індекс плодючості. Встановлено, що з кожною наступною генерацією вік першого плідного осіменіння телиць та першого отелення корів знижувався, що обумовило зниження живої маси тварин у зазначені фізіологічні періоди. В обох підконтрольних стадах за більшістю досліджуваних ознак репродуктивної здатності між коровами та їх потомками різних генерацій спостерігалася достовірна різниця, при цьому кожне наступне покоління тварин відзначалося кращою репродуктивною функцією ніж попереднє. В цілому потомки різних генерацій відзначалися доброю плодючістю, а їх предки - середньою, на що вказує однойменний індекс. Індекс плодючості у потомків, залежно від генерації та лактації, знаходився в межах 47,8-52,1, а в предків - в межах 40,2-43,6. Між ознаками репродуктивної здатності корів та їх дочок, внучок і правнучок спостерігалися слабкі різного напряму зв'язки, які здебільшого були недостовірними. Низька співвідносна мінливість досліджуваних ознак свідчить про низький рівень успадковуваності відтворних якостей потомками.

Ключові слова: корови, дочки, онучки, правнучки, показники відтворювальної здатності, коефріцієнти кореляції.

DOI: https://doi.org/10.32845/bsnau.Ivst.2019.4.3

3 метою поліпшення продуктивних ознак вітчизняної худоби впродовж тривалого часу в Україні використовувався геносронд голштинської породи. 3 кожним наступним поколінням умовна кровність корів вітчизняної худоби за

голштинською породою постійно зростає, спричиняючи неоднозначний ефект не лише на показники молочної продуктивності, але й на ознаки відтворювальної здатності потомків різних генерацій [14].

Вісник Сумського національного аграрного університету 
Останнім часом більшість дослідників вказують на погіршення репродуктивних якостей великої рогатої худоби: подовжується тривалість сервіс- і міжотельного періодів, зростає індекс осіменіння, знижується вихід телят на 100 корів, тварин вибраковують зі стада впродовж першої-другої лактацій через порушення відтворення і гінекологічні хвороби [3, 19, 21]. Причинами цього називають спрямовану однобічну селекцію на зростання надою, а також ембріональну смертність, незадовільну роботу техніка штучного осіменіння, високу скупченість тварин, їх захворюваність, використання голштинських плідників тощо $[6,12,18]$.

Останнім часом у літературних джерелах все частіше з'являються повідомлення про те, що показники відтворювальної здатності тварин зумовлюються генетичними чинниками, такими як належність до породи, типу, генотипу, ліній, походженням за батьком, методу підбору тощо $[1,2,4,5,7,8,11,15,16,17,20]$. Однак, на даний час недостатньо вивчено вплив матерів на показники відтворювальної здатності їх потомків різних поколінь. Відомо, що вплив материнського організму різноманітний - від середовища ембріонального розвитку теляти до передачі певного генетичного матеріалу. Материнський ефект в селекції сільськогосподарських тварин може бути як позитивним, так і негативним [10].

3 огляду на зазначене метою наших досліджень було вивчити відтворювальну здатність корів та їх потомків різних генерацій у високопродуктивних стадах (середній надій на корову близько 10000 кг).

Матеріали та методи досліджень. Дослідження проведені на коровах стад ТОВ «Велетень» Сумської області $(n=1956)$ та ПАТ «Племзавод "Стєпной"» Запорізької області (n=1981), створених за поглинального схрещування маток української чорно-рябої молочної породи з голштинськими плідниками. У корів і їх потомків різних генерацій на основі ретроспективного аналізу даних за період з 2004 по 2017 рр. (програма управління молочним стадом «ЮніформАгрі») та результатів власних досліджень вивчали: тривалість тільності, періоду від отелення до першого осіменіння (індепенденс-період), сервіс-, сухостійного та міжотельного періодів, коефіцієнт відтворювальної здатності, вихід телят на 100 корів, індекс осіменіння та індекс плодючості. Тривалість біологічних періодів у корів визначали за загальновідомими методами.

Коефіцієнт відтворювальної здатності (КВ3) визначали за формулою Д.Т. Вінничука, наведеною Й.3.Сірацьким та ін. [13]:

$$
K B 3=\frac{365}{M O \Pi},
$$

де 365 - кількість днів у році;

МОП - міжотельний період, днів.

Можливий вихід телят $(B T)$ на 100 корів обчислювали за формулою В. Ф. Бочарова, наведеною Й.З.Сірацьким та ін. [13]:

$$
B T=\frac{365 \times 100}{C+T},
$$

де 365 - кількість днів у році;

C - середня тривалість сервіс-періоду, днів;

$T$ - тривалість тільності, днів.

Індекс плодючості (ІП) вираховували за формулою
Й. Дохи, наведеною Й.3.Сірацьким та ін. [13]:

$$
I \Pi=100-(K+2 \cdot M O \Pi) \text {, }
$$

де $K$ - вік корови при першому отеленні, місяці;

МОП - середній міжотельний період, місяці

Коефіцієнти кореляції (r) ознак відтворювальної здатності у тварин різних поколінь, їх характер, напрям і величину вираховували за загальновідомою формулою.

Статистичну обробку даних здійснювали за допомогою програмного пакету Microsoft Excel за Г. Ф. Лакиным [9]. Результати середніх значень вважали статистично вірогідними при $\mathrm{P}<0,05\left(^{*}\right), \mathrm{P}<0,01\left(^{* *}\right), \mathrm{P}<0,001\left(^{* *}\right)$.

Результати досліджень. Темпи відтворення молочної худоби значною мірою зумовлюють вік першого плідного осіменіння (парування) телиць і першого отелення корів та їх жива маса у зазначені фізіологічні періоди.

Встановлено, що вік першого осіменіння у корівматерів у ТОВ «Велетень» та в ПАТ «Племзавод "Стєпной"» становив відповідно 21,5 та 18,4, а вік першого отелення 30,7 та 27,5 місяця. За цими показниками потомки першого покоління поступалися своїм предкам у першому господарстві відповідно на 5,3 та 5,4, а в другому - на 3,0 та 3,1 місяця, потомки другого покоління - на 5,5 та 5,0 місяців при $\mathrm{P}<0,001$ у всіх випадках. У ПАТ «Племзавод “Стєпной”» різниця за віком першого осіменіння та першого отелення між правнучками та їх предками становила 5,4 місяця при $P<0,001$ в обох випадках.

Важливим елементом тривалого господарського використання корів $€$ їх жива маса при першому плідному осіменінні та першому отеленні. Ці показники у корів-матерів у ТОВ «Велетень» становили відповідно 420,2 та 581,4, а у ПАТ «Племзавод “Стєпной”» - 397,4 та 573,4 кг, що високовірогідно більше, ніж у потомків першої генерації у першому господарстві на 61,8 та 49,9 , у другому - на 38,7 та 35,1 кг.

У ПАТ «Племзавод "Стєпной”» була вивчена також жива маса при першому плідному осіменінні та першому отеленні у правнучок. Вона становила відповідно 353,2 та 528,5 , що менше, ніж у їх предків на 54,0 та 49,8 кг при $\mathrm{P}<0,001$ в обох випадках. Таку значну різницю за вищенаведеними показниками між тваринами зазначених категорій можна пояснити значно молодшим віком першого осіменіння та першого отелення потомків досліджуваних поколінь.

Результати наших досліджень свідчать, що в обох підконтрольних стадах майже за всіма досліджуваними ознаками репродуктивної здатності між коровами та їх дочками спостерігалася достовірна різниця (табл. 1). Зокрема, диференціація за тривалістю сервіс-періоду за першу лактацію між вищенаведеними групами тварин у ТОВ «Велетень» становила 24,5 ( $\mathrm{P}<0,001)$, за вищу лактацію - 24,8 $(\mathrm{P}<0,001)$, за тривалістю міжотельного періоду - 24,8 $(\mathrm{P}<0,001)$ та $23,7(\mathrm{P}<0,001)$ і сухостійного - 2,9 $(\mathrm{P}<0,01)$ та 2,2 дня $(P<0,01)$ відповідно. У ПАТ «Племзавод "Стєпной”» у дочок порівняно з матерями тривалість сервіс-періоду була коротшою за першу лактацію на 31,3 , за вищу - на 38,5, міжотельного періоду - відповідно на 31,5 та 39,1 і сухостійного - на 2,2 та 1,5 дня, причому у всіх випадках, за винятком тривалості сухостійного періоду, різниця була високодостовірною.

Однією із важливих ознак, яка дає уявлення про репродуктивну функцію тварин, $є$ коефріцієнт відтворювальної здатності. За цим показником за першу лактацію матері

Вісник Сумського національного аграрного університету Серія «Тваринництво», випуск 4 (39), 2019 
поступалися дочкам у ТОВ «Велетень» на 0,04 (P<0,001), за вищу - на 0,05 ( $<<0,001)$, а у ПАТ «Племзавод "Стєпной"» за обидві названі лактації на 0,06 (P<0,001).

У вітчизняній практиці репродуктивну здатність корів на груповому рівні (у межах популяції і року) оцінюють за показником виходу телят на 100 корів. При визначенні цього показника враховують також народжених двійнят, отелення нетелей та корів, що отелилися двічі на рік. За виходом телят на 100 корів кращими знову виявилися дочки. Їх перевага над матерями за цим показником за першу та вищу лактації у ТОВ «Велетень» становила 4,6 (P<0,001), а у ПАТ «Племзавод “Стєпной”» - відповідно 5,6 та 6,8 гол.

Важливе значення у комплексній оцінці репродуктивної здатності тварин має їх плодючість. Отримані нами результати досліджень свідчать, що корови-матері в обох підконтрольних стадах характеризувалися середньою пло- дючістю, а їх дочки - доброю. Плодючість корів вважається доброю, якщо однойменний індекс становить 48 і більше, середньою - якщо цей індекс знаходиться в межах 41-47 і низькою - якщо його значення не перевищує 40.

За тривалістю тільності та індепенденс-періоду різниця між наведеними групами тварин у ТОВ «Велетень» була несуттєвою, а за індексом осіменіння матері переважали дочок за першу та вищу лактації на 0,5 при $\mathrm{P}<0,001$ в обох випадках. У ПАТ «Племзавод “Стєпной”» за тривалістю тільності різниця між коровами та їх потомками першого покоління була незначною, а за тривалістю індепенденсперіоду була високовірогідною і за першу лактацію становила 12,2, за вищу - 6,2 дня. За індексом осіменіння дочки поступалися своїм матерям за наведені вище лактації відповідно на 0,2 $(\mathrm{P}<0,05)$ та 0,7 ( $<<0,001)$.

Відтворювальна здатність матерів і їх дочок за першу лактацію, M士m

\begin{tabular}{|c|c|c|c|c|}
\hline \multirow{2}{*}{ Ознака } & \multicolumn{2}{|c|}{ ТОВ «Велетень» (n=648 пар) } & \multicolumn{2}{|c|}{ ПАТ «Племзавод “Стєпной”» (n=899 пар) } \\
\hline & матері & дочки & матері & дочки \\
\hline \multicolumn{5}{|c|}{ Перша лактація } \\
\hline $\begin{array}{l}\text { Тривалість періодів, дні: } \\
\text { тільності }\end{array}$ & $278,9 \pm 0,31$ & $278,7 \pm 0,28$ & $277,6 \pm 0,25$ & $277,4 \pm 0,26$ \\
\hline індепенденс-періоду & $68,7 \pm 1,01$ & $68,6 \pm 0,38$ & $77,7 \pm 1,14$ & $65,5 \pm 0,73^{* * *}$ \\
\hline сервіс-періоду & $142,6 \pm 3,40$ & $118,1 \pm 2,63^{* * t}$ & $160,4 \pm 3,63$ & $129,1 \pm 2,99^{* * *}$ \\
\hline сухостійного & $62,6 \pm 0,72$ & $59,7 \pm 0,62^{* *}$ & $57,3 \pm 0,62$ & $55,1 \pm 0,51^{* *}$ \\
\hline міжотельного & $421,5 \pm 3,39$ & $396,7 \pm 2,62^{* * *}$ & $438,0 \pm 3,63$ & $406,5 \pm 2,98^{* * *}$ \\
\hline KB3 & $0,90 \pm 0,006$ & $0,94 \pm 0,005^{* * t}$ & $0,87 \pm 0,006$ & $0,93 \pm 0,005^{* * t}$ \\
\hline Вихід телят на 100 корів, гол. & $89,5 \pm 0,58$ & $94,1 \pm 0,50^{* * *}$ & $87,5 \pm 0,58$ & $93,1 \pm 0,52^{* * *}$ \\
\hline Індекс осіменіння & $2,7 \pm 0,068$ & $2,2 \pm 0,062^{* * *}$ & $2,7 \pm 0,07$ & $2,5 \pm 0,07^{\star}$ \\
\hline Індекс плодючості & $41,6 \pm 0,27$ & $48,6 \pm 0,21^{* * *}$ & $43,5 \pm 0,26$ & $48,8 \pm 0,22^{* * *}$ \\
\hline \multicolumn{5}{|c|}{ Вища лактація } \\
\hline $\begin{array}{l}\text { Тривалість періодів, дні: } \\
\text { тільності }\end{array}$ & $277,9 \pm 0,36$ & $278,7 \pm 0,29$ & $277,2 \pm 0,26$ & $276,6 \pm 0,27$ \\
\hline індепенденс-періоду & $66,92 \pm 0,64$ & $68,90 \pm 0,39^{* *}$ & $72,4 \pm 1,07$ & $66,2 \pm 0,73^{* * *}$ \\
\hline сервіс-періоду & $145,2 \pm 3,29$ & $120,4 \pm 2,71^{* *+*}$ & $183,4 \pm 3,96$ & $144,9 \pm 3,36^{* *+*}$ \\
\hline сухостійного & $68,1 \pm 1,01$ & $60,2 \pm 0,66^{* *}$ & $57,1 \pm 0,68$ & $55,6 \pm 0,66$ \\
\hline міжотельного & $423,0 \pm 3,31$ & $399,3 \pm 2,71^{* * *}$ & $460,5 \pm 3,95$ & $421,4 \pm 3,36^{* * *}$ \\
\hline KB3 & $0,89 \pm 0,006$ & $0,94 \pm 0,005^{* * *}$ & $0,84 \pm 0,006$ & $0,90 \pm 0,006^{*+*}$ \\
\hline Вихід телят на 100 корів, гол. & $89,0 \pm 0,56$ & $93,6 \pm 0,51^{* * *}$ & $83,6 \pm 0,59$ & $90,4 \pm 0,56^{* * *}$ \\
\hline Індекс осіменіння & $2,8 \pm 0,067$ & $2,3 \pm 0,062^{* * *}$ & $3,5 \pm 0,08$ & $2,8 \pm 0,07^{\star \star *}$ \\
\hline Індекс плодючості & $41,7 \pm 0,26$ & $48,5 \pm 0,22^{* * *}$ & $41,8 \pm 0,28$ & $47,8 \pm 0,24^{* * *}$ \\
\hline
\end{tabular}

Слід відмітити, що коефіцієнти варіації досліджуваних ознак відтворювальної здатності у підконтрольного поголів'я корів-матерів у першому господарстві, залежно від ознаки та лактації, знаходилася в межах 2,8-65,3, у другому - в межах 2,7-71,5, а у дочок - відповідно в межах 2,5-70,3 та 2,8-78,5\%, причому в обох господарствах за обидві досліджувані лактації найменшою мінливістю відзначалася тривалість тільності, а найвищою - тривалість сервісперіоду та індекс осіменіння.

Більш суттєва різниця за показниками репродуктивної функції відмічена між коровами та їх внучками (табл. 2). За тривалістю тільності за першу та вищу лактації у ТОВ «Велетень» вона становила відповідно $1,8(\mathrm{P}<0,05)$ та 0,1, індепенденс-періоду - 3,2 та 1,8, сервіс-періоду - 15,5 $(P<0,05)$ та $33,3 \quad(P<0,001)$, сухостійного періоду - 4,2 $(\mathrm{P}<0,05)$ та $11,7(\mathrm{P}<0,001)$ і міжотельного періоду - 17,3 $(P<0,05)$ та 33,2 дня $(P<0,001)$, а у ПАТ «Племзавод "Стєп- ной"» - відповідно 0,5 та 1,$3 ; 20,1 \quad(P<0,001)$ та 10,9 $(P<0,001), 67,9(P<0,001)$ та $71,0(P<0,01) ; 5,0(P<0,01)$ та 4,7 $(P<0,05)$ i $68,4(P<0,001)$ та 72,3 $(P<0,001)$.

За коефіцієнтом відтворювальної здатності, виходом телят на 100 корів та індексом плодючості за першу лактацію онучки переважали своїх предків у першому господарстві відповідно на 0,03 ( $\mathrm{P}<0,05), 3,3$ гол. $(\mathrm{P}<0,01)$ та 6,8 ( $\mathrm{P}<0,001)$, а у другому - на 0,12; 12,1 гол. та 9,7 при $\mathrm{P}<0,001$ у всіх випадках. За вищу лактацію ця перевага у всіх випадках також була високовірогідною і становила відповідно 0,07; 7,0 гол. та 7,7 і 0,12; 12,9 гол. та 10,0. Більшу кількість осіменінь на одне плідне (індекс осіменіння) за вищенаведені лактації відмічено у матерів матерів. За цим показником за першу лактацію вони переважали внучок у ТОВ «Велетень» на 0,2, за вищу - на 0,7 ( $P<0,001)$, а у ПАТ «Племзавод "Стєпной"» - на 0,8 та 1,2 при $\mathrm{P}<0,001$ в обох випадках. 
Таблиця 2

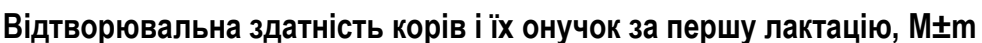

\begin{tabular}{|c|c|c|c|c|}
\hline \multirow{2}{*}{ Ознака } & \multicolumn{2}{|c|}{ ТОВ «Велетень» (n=121 пар) } & \multicolumn{2}{|c|}{ ПАТ «Племзавод “Стєпной”» (n=265 пар) } \\
\hline & корови & онучки & корови & онучки \\
\hline \multicolumn{5}{|c|}{ Перша лактація } \\
\hline \begin{tabular}{|l|} 
Tривалість періодів, дні: \\
тільності \\
\end{tabular} & $278,6 \pm 0,67$ & $276,8 \pm 0,60^{*}$ & $277,7 \pm 0,36$ & $277,2 \pm 0,32$ \\
\hline індепенденс-періоду & $65,3 \pm 1,53$ & $68,5 \pm 0,88$ & $88,0 \pm 2,59$ & $67,9 \pm 1,20^{* * *}$ \\
\hline сервіс-періоду & $128,4 \pm 6,23$ & $112,9 \pm 4,92^{*}$ & $182,2 \pm 7,24$ & $114,3 \pm 4,62^{* * *}$ \\
\hline сухостійного & $61,5 \pm 1,49$ & $57,3 \pm 1,47^{\star}$ & $58,7 \pm 1,50$ & $53,7 \pm 0,99^{* *}$ \\
\hline міжотельного & $406,9 \pm 6,45$ & $389,7 \pm 4,99^{*}$ & $459,9 \pm 7,25$ & $391,5 \pm 4,61^{* * *}$ \\
\hline KB3 & $0,92 \pm 0,011$ & $0,95 \pm 0,010^{*}$ & $0,84 \pm 0,011$ & $0,96 \pm 0,009^{* * *}$ \\
\hline Вихід телят на 100 корів, гол. & $92,0 \pm 1,24$ & $95,3 \pm 1,08^{*}$ & $83,7 \pm 1,08$ & $95,8 \pm 0,86^{* * *}$ \\
\hline Індекс осіменіння & $2,4 \pm 0,116$ & $2,2 \pm 0,117$ & $2,8 \pm 0,11$ & $2,0 \pm 0,10^{* * *}$ \\
\hline Індекс плодючості & $43,6 \pm 0,51$ & $50,4 \pm 0,37^{\star \star *}$ & $41,0 \pm 0,47$ & $50,7 \pm 0,33^{* * *}$ \\
\hline \multicolumn{5}{|c|}{ Вища лактація } \\
\hline $\begin{array}{l}\text { Tривалість періодів, дні: } \\
\text { тільності }\end{array}$ & $277,0 \pm 0,92$ & $277,1 \pm 0,59$ & $278,1 \pm 0,32$ & $276,8 \pm 0,34^{* *}$ \\
\hline індепенденс-періоду & $65,6 \pm 1,30$ & $67,4 \pm 0,77$ & $79,2 \pm 2,24$ & $68,3 \pm 1,21^{* * *}$ \\
\hline сервіс-періоду & $140,6 \pm 6,10$ & $107,3 \pm 4,55^{* * *}$ & $192,1 \pm 7,14$ & $121,1 \pm 4,74^{* * *+}$ \\
\hline сухостійного & $68,8 \pm 2,40$ & $57,1 \pm 1,44^{* \star *}$ & $58,2 \pm 1,53$ & $53,5 \pm 1,01^{*}$ \\
\hline міжотельного & $417,6 \pm 6,26$ & $384,4 \pm 4,59^{* * *}$ & $470,2 \pm 7,10$ & $397,9 \pm 4,74^{* *+*}$ \\
\hline KB3 & $0,89 \pm 0,012$ & $0,96 \pm 0,010^{* * *}$ & $0,82 \pm 0,010$ & $0,94 \pm 0,009^{* * *}$ \\
\hline Вихід телят на 100 корів, гол. & $89,4 \pm 1,18$ & $96,4 \pm 1,01^{* \star *}$ & $81,6 \pm 1,03$ & $94,5 \pm 0,88^{* * *}$ \\
\hline Індекс осіменіння & $2,8 \pm 0,128$ & $2,1 \pm 0,111^{* \star *}$ & $3,3 \pm 0,14$ & $2,1 \pm 0,10^{* * *}$ \\
\hline Індекс плодючості & $43,0 \pm 0,47$ & $50,7 \pm 0,35^{* \star *}$ & $40,2 \pm 0,48$ & $50,2 \pm 0,34^{* * *}$ \\
\hline
\end{tabular}

У ПАТ «Племзавод "Стєпной”» певна диференціація за показниками репродуктивної функції за вищенаведені лактації нами була виявлена також між коровами і їх правнучками, причому у більшості випадків вона була вірогідною (табл. 3).

Слід зазначити, що за тривалістю тільності, коефіцієнтом відтворювальної здатності, виходом телят на 100 корів і індексом плодючості за обидві досліджувані лактації та за тривалістю сухостійного періоду за вищу лактацію перевага була на боці правнучок, а за тривалістю індепенденс-, сервіс- і міжотельного періодів та індексом осіменіння корови переважали своїх потомків третьої генерації.

Таким чином, результати наших досліджень свідчать, що кожне наступне покоління корів відзначалося кращою відтворювальною здатністю. Мабуть, це можна пояснити своєчасним вибракуванням ялових та стимуляцією неплідних корів, а також покращеним рівнем годівлі.

Відтворювальна здатність корів і їх правнучок за першу та вищу лактації у ПАТ «Племзавод “Стєпной"», n=16

\begin{tabular}{|c|c|c|c|c|}
\hline \multirow{2}{*}{ Ознака } & \multicolumn{2}{|c|}{ Корови } & \multicolumn{2}{|c|}{ Правнучки } \\
\hline & $M \pm m$ & $\mathrm{Cv}_{\mathrm{v}, \%}$ & $\mathrm{M} \pm \mathrm{m}$ & $\mathrm{Cv}_{\mathrm{v}} \%$ \\
\hline \multicolumn{5}{|c|}{ Перша лактація } \\
\hline $\begin{array}{l}\text { Тривалість періодів, дні: } \\
\text { тільності }\end{array}$ & $275,5 \pm 2,67$ & 3,9 & $276,9 \pm 1,54$ & 2,2 \\
\hline індепенденс-періоду & $92,3 \pm 9,76$ & 43,2 & $71,1 \pm 3,48^{*}$ & 20,1 \\
\hline сервіс-періоду & $185,4 \pm 30,39$ & 65,6 & $102,1 \pm 17,48^{*}$ & 68,5 \\
\hline сухостійного & $61,6 \pm 9,27$ & 60,2 & $50,1 \pm 3,68$ & 29,4 \\
\hline міжотельного & $460,9 \pm 29,00$ & 25,2 & $379,0 \pm 18,43^{\star}$ & 19,5 \\
\hline KB3 & $0,83 \pm 0,037$ & 18,0 & $0,99 \pm 0,034^{* *}$ & 13,6 \\
\hline Вихід телят на 100 корів, гол. & $82,6 \pm 3,72$ & 18,0 & $98,8 \pm 3,36^{* *}$ & 13,6 \\
\hline Індекс осіменіння & $2,7 \pm 0,38$ & 57,2 & $1,6 \pm 0,38^{*}$ & 92,3 \\
\hline Індекс плодючості & $41,8 \pm 1,85$ & 17,8 & $52,1 \pm 1,21^{\star \star *}$ & 9,3 \\
\hline \multicolumn{5}{|c|}{ Вища лактація } \\
\hline $\begin{array}{l}\text { Тривалість періодів, дні: } \\
\text { тільності }\end{array}$ & $276,4 \pm 2,76$ & 4,0 & $276,9 \pm 1,54$ & 2,2 \\
\hline індепенденс-періоду & $90,0 \pm 9,52$ & 42,3 & $71,1 \pm 3,58$ & 20,1 \\
\hline сервіс-періоду & $177,3 \pm 32,21$ & 72,7 & $102,1 \pm 17,48^{*}$ & 68,5 \\
\hline сухостійного & $47,6 \pm 4,88$ & 41,0 & $50,1 \pm 3,68$ & 29,4 \\
\hline міжотельного & $453,7 \pm 30,62$ & 27,0 & $379,0 \pm 18,43^{*}$ & 19,5 \\
\hline KB3 & $0,84 \pm 0,042$ & 19,9 & $0,99 \pm 0,034^{* *}$ & 13,6 \\
\hline Вихід телят на 100 корів, гол. & $84,4 \pm 4,21$ & 19,9 & $98,8 \pm 3,36^{* *}$ & 13,6 \\
\hline Індекс осіменіння & $2,5 \pm 0,39$ & 62,0 & $1,6 \pm 0,38$ & 92,3 \\
\hline Індекс плодючості & $42,4 \pm 1,96$ & 18,5 & $52,1 \pm 1,21^{* \star *}$ & 9,3 \\
\hline
\end{tabular}


Важливе значення у селекції молочної худоби має визначення коефріцієнтів кореляції між окремими ознаками відтворювальної здатності корів та їх потомків. Аналіз співвідносної мінливості показав різний рівень та напрям зв'язків між ознаками репродуктивної функції матерів та цими ж ознаками у їх дочок, онучок та правнучок (табл. 4).

За першу та вищу лактації між більшістю досліджуваних ознак відтворювальної здатності корів та їх дочок у ТОВ «Велетень» коефіцієнти кореляції були додатні і майже у всіх випадках вірогідні. Залежно від показника та лактації вони знаходилися в межах 0,012-0,131, причому найвищий рівень їх був між тривалістю тільності, коефіцієнтом відтворювальної здатності та виходом телят на 100 корів, а найнижчий - між показниками індексу плодю- чості та тривалості індепенденс-періоду у матерів та їх дочок.

Зв'язки між досліджуваними ознаками репродуктивної здатності корів та їх дочок у ПАТ «Племзавод "Стєпной”» були низькими різнонаправленими і здебільшого невірогідними. Співвідносна мінливість ознак репродуктивної здатності корів та їх внучок була також низькою невірогідною і здебільшого від'ємною, що вказує, на нашу думку, на низьку успадковуваність ознак відтворювальної функції. Водночас зв'язки між вищенаведеними ознаками у корів та їх правнучок були сильнішими, проте різнонаправленими і здебільшого невірогідними, проте остаточний висновок у даному випадку робити некоректно через незначну кількість тварин у вибірці.

Таблиця 4

Зв'язок ознак відтворювальної здатності тварин з цими ознаками у їх потомків, $r \pm m_{r}$

\begin{tabular}{|c|c|c|c|c|c|}
\hline \multirow{3}{*}{ Ознака } & \multicolumn{2}{|c|}{ ТОВ «Велетень» } & \multicolumn{3}{|c|}{ ПАТ «Племзавод “Стєпной”» } \\
\hline & \multicolumn{5}{|c|}{ Поєднання ознак відтворювальної здатності у корів та їх: } \\
\hline & дочок (n=648) & онучок $(n=121)$ & дочок (n=899) & онучок $(n=265)$ & правну-чок $(n=16)$ \\
\hline \multicolumn{6}{|c|}{ Перша лактація } \\
\hline $\begin{array}{l}\text { Тривалість періодів, дні: } \\
\text { тільності } \\
\end{array}$ & $0,13 \pm 0,039^{\star \star \star}$ & $0,21 \pm 0,088^{*}$ & $0,06 \pm 0,033$ & $-0,04 \pm 0,061$ & $0,33 \pm 0,222$ \\
\hline індепенденс-періоду & $0,02 \pm 0,039$ & $-0,04 \pm 0,092$ & $0,02 \pm 0,033$ & $-0,06 \pm 0,061$ & $-0,28 \pm 0,230$ \\
\hline сервіс-періоду & $0,09 \pm 0,039^{*}$ & $-0,10 \pm 0,091$ & $-0,03 \pm 0,033$ & $-0,04 \pm 0,061$ & $0,37 \pm 0,215$ \\
\hline сухостійного & $0,10 \pm 0,039^{*}$ & $0,02 \pm 0,091$ & $-0,02 \pm 0,033$ & $-0,11 \pm 0,061$ & $-0,25 \pm 0,234$ \\
\hline міжотельного & $0,08 \pm 0,039^{*}$ & $-0,07 \pm 0,091$ & $0,05 \pm 0,033$ & $-0,05 \pm 0,061$ & $0,34 \pm 0,221$ \\
\hline KB3 & $0,13 \pm 0,039^{* \star *}$ & $-0,03 \pm 0,092$ & $0,06 \pm 0,033$ & $-0,04 \pm 0,061$ & $0,45 \pm 0,199^{*}$ \\
\hline Вихід телят на 100 корів, гол. & $0,13 \pm 0,039^{* * *}$ & $-0,03 \pm 0,092$ & $0,06 \pm 0,033$ & $-0,04 \pm 0,061$ & $0,45 \pm 0,199^{*}$ \\
\hline Індекс осіменіння & $0,11 \pm 0,039^{* \star}$ & $-0,01 \pm 0,092$ & $0,04 \pm 0,033$ & $-0,02 \pm 0,061$ & $0,26 \pm 0,233$ \\
\hline Індекс плодючості & $0,02 \pm 0,039$ & $-0,06 \pm 0,091$ & $0,11 \pm 0,033^{* \star}$ & $-0,02 \pm 0,061$ & $0,29 \pm 0,229$ \\
\hline \multicolumn{6}{|c|}{ Вища лактація } \\
\hline $\begin{array}{l}\text { Тривалість періодів, дні: } \\
\text { тільності }\end{array}$ & $0,11 \pm 0,039^{* *}$ & $0,06 \pm 0,091$ & $0,05 \pm 0,033$ & $-0,02 \pm 0,061$ & $0,33 \pm 0,222$ \\
\hline індепенденс-періоду & $0,02 \pm 0,039$ & $0,05 \pm 0,091$ & $0,02 \pm 0,033$ & $-0,13 \pm 0,060^{*}$ & $-0,12 \pm 0,246$ \\
\hline сервіс-періоду & $0,09 \pm 0,039^{*}$ & $-0,07 \pm 0,091$ & $-0,01 \pm 0,033$ & $0,02 \pm 0,061$ & $0,33 \pm 0,222$ \\
\hline сухостійного & $0,03 \pm 0,039$ & $-0,09 \pm 0,090$ & $-0,01 \pm 0,033$ & $-0,05 \pm 0,061$ & $-0,13 \pm 0,246$ \\
\hline міжотельного & $0,08 \pm 0,039^{*}$ & $-0,03 \pm 0,092$ & $0,05 \pm 0,033$ & $-0,03 \pm 0,061$ & $0,37 \pm 0,217$ \\
\hline KB3 & $0,12 \pm 0,039^{* *}$ & $0,03 \pm 0,092$ & $0,08 \pm 0,033^{*}$ & $-0,02 \pm 0,061$ & $0,47 \pm 0,195^{*}$ \\
\hline Вихід телят на 100 корів, гол. & $0,12 \pm 0,039^{\star *}$ & $0,03 \pm 0,092$ & $0,08 \pm 0,033^{*}$ & $-0,02 \pm 0,061$ & $0,47 \pm 0,195^{*}$ \\
\hline Індекс осіменіння & $0,10 \pm 0,039^{* *}$ & $-0,03 \pm 0,092$ & $0,04 \pm 0,033$ & $-0,05 \pm 0,061$ & $0,29 \pm 0,229$ \\
\hline Індекс плодючості & $0,01 \pm 0,039$ & $-0,08 \pm 0,091$ & $0,09 \pm 0,033^{* *}$ & $0,01 \pm 0,061$ & $0,33 \pm 0,223$ \\
\hline
\end{tabular}

Висновки. 1. Встановлено, що з кожною наступною генерацією вік першого плідного осіменіння телиць та першого отелення корів знижувався, що обумовило зниження живої маси тварин у зазначені фізіологічні періоди.

2. В обох підконтрольних стадах за більшістю досліджуваних ознак репродуктивної здатності між коровами та їх потомками різних генерацій спостерігалася достовірна різниця, при цьому кожне наступне покоління тварин відзначалося кращою репродуктивною функцією ніж попереднє. В цілому потомки різних генерацій відзначалися доброю пло- дючістю, а їх предки - середньою, на що вказує однойменний індекс. Індекс плодючості у потомків, залежно від генерації та лактації, знаходився в межах 47,8-52,1, а в предків - в межах 40,2-43,6.

3. Між ознаками репродуктивної здатності корів та їх дочок, внучок і правнучок спостерігалися слабкі різного напряму зв'язки, які здебільшого були недостовірними. Низька співвідносна мінливість досліджуваних ознак свідчить про низький рівень успадковуваності відтворних якостей потомками.

\section{Список використаної літератури:}

1.Боднар, П. В., Щербатий, З. Є., Федорович, Є.І. Вплив генотипу на відтворну здатність тварин. Біологія тварин : науковий журнал. Інститут біології тварин НААН. Львів, 2014. Т. 16, № 3. С. 17-22.

2.Щербатий, 3. Є., Козенко, О. В., Боднар, П. В., Боднарук, В. Є. Відтворна здатність телиць та корів-первісток української чорно-рябої молочної породи різного походження. Науковий вісник Львівського національного університету ветеринарної медищини та біотехнологій імені С. 3. Гжицького. Серія “Сільськогосподарські науки”. Львів, 2016. Т. 18, № 1 (65), 4. 3. C. 177-184.

3.Гончарук, М. С. Аналіз порушення відтворення у стаді молочної худоби. Розведення і генетика тварин. 2018. Вип. 55. С. 179-186. 
4.Жигачев, А. И., Уколов, П. И., Вилль, А. В. Разведение сельскохозяйственных животных с основами частной зоотехнии : учебник. Москва: КолосС, 2009. - 408 с.

5.Жукова, И. Г., Рудишина, Н. М. Влияние возраста первого осеменения телок на их молочную продуктивность и воспроизводительные качества. Аграрная наука - сельскому хозяйству: сборник статей: в 3 кн. VII Международ. науч.-nракт. конф. Барнаул: Алтайский ГАУ, 2012. Кн. 3. С. 105-107.

6.Козирь, В. Мовчан, Т. Підвищення надоїв може погіршити відтворення. Тваринництво України. 2010. №10. С. 1619.

7.Кузів, М.І., Федорович, Є.І.Відтворювальна здатність корів української чорно-рябої молочної породи. Науковий вісник Львівського національного університету ветеринарної медицини та біотехнологій імені С. З. Гжицького. Серія “Сільськогосподарські науки”. Львів, 2016. Т. 18, № 2 (67). С. 120-123. doi:10.15421/nvlvet6727.

8.Кузнецов, В. М. Воспроизводительная способность коров и селекция по молочной продуктивности. Международный научно-исследовательский журнал. Екатеринбург, 2016. №4 (46), Ч. 6. С. 50-52. DOI: 10.18454/IRJ.2016.46.280.

9.Лакин, Г. Ф. Биометрия : учебное пособие [для биол. спец. вузов]. - (4-е изд., перераб. и доп.). М. : Высшая школа, 1990. 352 c

10.Нежлукченко, Т. І. Використання материнського ефекту в селекції сільськогосподарських тварин. Генетика $і$ селекція в Україні на межі тисячоліть. К. : Логос, 2001. Т. 4. С. 281-285.

11.Новак, І. В., Федорович, В. В., Федорович, Є.І. Вплив віку першого плідного осіменіння і першого отелення на формування молочної продуктивності корів української чорно-рябої молочної породи. Біологія тварин : науково теоретичний журнал. Інститут біології тварин НААН. Львів, 2012. Т. 14, №1-2. С. 486-490.

12.Підпала, Т. Цхвітава, О., Ясєвін, С. Відтворення великої рогатої худоби за безприв'язного утримання. Тваринниитво України. 2011. №7. С. 10-12.

13.Сірацький, Й. 3., Федорович, Є. І., Кадиш, В. О. Методи оцінки відтворної здатності худоби. Методики наукових досліджень із селекції, генетики та біотехнології у тваринниитві. К.: Аграрна наука, 2005. С. 175-178.

14.Хмельничий, Л. М., Вечорка, В.В.Вплив частки спадковості голштинської породи та методів підбору на господарськи корисні ознаки корів молочної худоби. Розведення і генетика тварин. 2018. Вип. 55. С. 135-142.

15.Щербатий, 3. Є., Боднар, П. В., Боднарук, В. Є. Відтворна здатність телиць та корів-первісток української чорнорябої молочної породи різних ліній. Науковий вісник Львівського національного університету ветеринарної медицини та біотехнологій імені С. З. Гжицького. Серія “Сільськогосподарські науки”. Львів, 2015. Т. 17, № 1 (61), Ч. 3. С. $286-293$.

16.Щербатий, 3. Є., Боднар, П. В., Кропивка, Ю. Г. Молочна продуктивність та відтворна здатність корів української чорно-рябої молочної породи різних типів конституції. Науковий вісник Львівського національного університету ветеринарної медицини та біотехнологій імені С. З. Гжицького. Серія “Сільськогосподарські науки”. Львів, 2017. Т. 19 , №74. C. 182-187 doi:10.15421/nvlvet7440.

17.Юдин, В. М., Любимов, А. И., Никитин, К. П. Селекция черно-пестрой породы крупного рогатого скота с использованием различных методов племенного подбора. Известия Самарской государственной сельскохозяйственной академии. 2016. Вып. 1. С. 37-40. DOI 10.12737/18326.

18.Hudson C. D., Bradley A. J., Breen J. E., Green M. J. Associations between udder health and reproductive performance in United Kingdom dairy cows. Journal of Dairy Science. 2012. Vol. 95. №7. P. 3683-3697.

19.Barth, A. D., Brito, L. F. C., Kastelic, J. P. The effect of nutrition on sexual development of bulls. Theriogenology. 2008. Vol. 70, Issue 3. P. 485-494.

20.Ferri, C. P., Heins, B. J., Buckley, F. Crossbreeding in Dairy Cattle: Pros and Cons. WCDS Advances in Dairy Technology. 2014, №26. P. 223-243.

21.Gonzalez-Recio, O., Alenda, R., Chang, Y. M., Weigel, K. A., Gianola, D. Selection for female fertility using censored fertility traits and investigation of the relationship with milk production. Journal of Dairy Science. 2006. Vol. 89. P. 4438-4444.

\section{References:}

1. Bodnar, P. V. Shcherbatyi, Z. Y. Fedorovych, E. I., 2014. Vplyv genotypu na vidtvornu zdatnist' tvaryn [The influence of genotype on reproductive ability of animals]. Biologija tvaryn - The Animal Biology,16 (3): 17-22.

2. Shcherbatyi, Z. Y., Kozenko, O. V., Bodnar, P. V., Bodnaruk, V. Y., 2016. Vidtvorna zdatnist' telyc' ta koriv-pervistok ukrai'ns'koi' chorno-rjaboi' molochnoi' porody riznogo pohodzhennja [Reproductive ability of heifers and cows firstborn of ukrainian black spotted dairy breed with different origin]. Naukovyj visnyk L'vivs'kogo nacional'nogo universytetu veterynarnoi' medycyny ta biotehnologij im. S. Z. Gzhyc'kogo. - Scientific Messenger of Lviv National University of Veterinary Medicine and Biotechnologies. Series: Agricultural sciences,18, 1 (65), 3: 177-184.

3. Goncharuk, M. S. 2018. Analiz porushennja vidtvorennja u stadi molochnoi' hudoby [Analysis of reproductive disorders in the dairy herd]. Rozvedennya i henetyka tvaryn - Animal Breeding and Genetics, 55: 179-186.

4. Zhigachev, A. I., Ukolov, P. I., Vill, A. V., 2009. Razvedenie sel'skohozjajstvennyh zhivotnyh s osnovami chastnoj zootehnii : uchebnik [Breeding farm animals with the basics of small animal science: Textbook]. Moskva: Kolos, 408.

5. Zhukova, I. G., Rudishina, N. M. 2012. Vlijanie vozrasta pervogo osemenenija telok na ih molochnuju produktivnost' i vosproizvoditel'nye kachestva [The influence of the age of the first insemination of heifers on their dairy productivity and reproductive qualities]. Agrarnaja nauka - sel'skomu hozjajstvu: sbornik statej VII Mezhdunarodoj nauchno-prakticheskoj konferencii - Agrarian Science to Agriculture: Collection of Articles of the VII International Scientific practical conference. Barnaul: Altai State Agricultural University, 3: 105-107.

6. Kozyr, V. Movchan, T., 2010. Pidvyshhennja nadoi'v mozhe pogirshyty vidtvorennja [Increasing of milk yield can impair 
reproduction]. Tvarynnycztvo Ukrayiny - Animal husbandry of Ukraine, 10: 16-19.

7. Kuziv, M. I., Fedorovych, E. I., 2016. Vidtvorjuval'na zdatnist' koriv ukrai'ns'koi' chorno-rjaboi' molochnoi' porody [Reppoductive ability of ukrainian black and white dairy cows]. Naukovyj visnyk L'vivs'kogo nacional'nogo universytetu veterynarnoi' medycyny ta biotehnologij im. S. Z. Gzhyc'kogo. - Scientific Messenger of Lviv National University of Veterinary Medicine and Biotechnologies. Series: Agricultural sciences, 18, 2 (67): 120-123. doi:10.15421/nvlvet6727.

8. Kuznetsov, B. M., 2016. Vosproizvoditel'naja sposobnost' korov i selekcija po molochnoj produktivnosti [Reproductive ability of cows and selective breeding for milk production]. Mezhdunarodnyj nauchno-issledovatel'skij zhurnal - International research journal, 4 (46), 6: 50-52. DOI: 10.18454/IRJ.2016.46.280.

9. Lakyn, H. F., 1990. Byometryia: uchebnoe posobye [dlia byol. spets. vuzov] Biometrics: a tutorial [for biol. specialist. Universities]. M.: Vysshaia shkola, 352.

10. Nezhlukchenko, T. I. 2001. Vykorystannja materyns'kogo efektu v selekcii' sil's'kogospodars'kyh tvaryn [The use of maternal effect in agricultural animals breeding]. Genetyka i selekcija v Ukrai'ni na mezhi tysjacholit' - Genetics and breeding in Ukraine at the Turn of the Millennium. - Kyiv : Lohos, 4: 281-285.

11. Novak, I. V., Fedorovych, V. V., Fedorovych, E. I., 2012. Vplyv viku pershogo plidnogo osimeninnja i pershogo otelennja na formuvannja molochnoi' produktyvnosti koriv ukrai'ns'koi' chorno-rjaboi' molochnoi' porody [Effect of studies of age first fruitful insemination and calving first in breast of performanse of cows ukrainian black-and-white dairy breed]. Biologija tvaryn - The Animal Biology, 14 (1-2): 486-490.

12. Pidpala, T. Chvitava O., Jasjevin, S., 2011. Vidtvorennja velykoi' rogatoi' hudoby za bezpryv'jaznogo utrymannja [Reproduction of cattle in the circumstances of unrestrained keeping]. Tvarynnycztvo Ukrayiny - Animal husbandry of Ukraine, 7: 10-12.

13. Siratskyi, Y. Z., Fedorovych, E. I., Kadysh V. O. 2005. Metody ocinky vidtvornoi' zdatnosti hudoby [Methods for assessing the reproducibility of livestock]. Metodyky naukovykh doslidzhen iz selektsiyi, henetyky ta biotekhnolohiyi u tvarynnytstvi Research methods in selection, genetics and biotechnology in stockbreeding. Kyiv, Ahrarna nauka, 175-178.

14. Khmelnychyi, L. M., Vecherka, V. V., 2018. Vplyv chastky spadkovosti golshtyns'koi' porody ta metodiv pidboru na gospodars'ky korysni oznaky koriv molochnoi' hudoby [The effect of share hereditability of holstein breed and methods for selection of economically useful traits of cows dairy cattle]. Rozvedennya i henetyka tvaryn - Animal Breeding and Genetics, 55: 135-142.

15. Shcherbatyj, Z. Y., Bodnar, P. V., Bodnaruk, V. Y., 2015. Відтворна здатність телиць та корів-первісток української чорно-рябої молочної породи різних ліній [Reproductive ability of heifers and cows firstborn of ukrainian black spotted dairy breed with different lines]. Naukovyj visnyk L'vivs'kogo nacional'nogo universytetu veterynarnoi' medycyny ta biotehnologij im. S. Z. Gzhyc'kogo. - Scientific Messenger of Lviv National University of Veterinary Medicine and Biotechnologies. Series: Agricultural sciences, 17, 1 (61), 3: 286-293.

16. Shcherbatyj, Z. Y., Bodnar, P. V., Kropyvka, Y. G., 2017. Molochna produktyvnist' ta vidtvorna zdatnist' koriv ukrai'ns'koi' chorno-rjaboi' molochnoi' porody riznyh typiv konstytucii' [Milk productivity and reproductive ability of ukrainian black-spotted dairy breed cows of different type of constitution]. Naukovyj visnyk L'vivs'kogo nacional'nogo universytetu veterynarnoi' medycyny ta biotehnologij im. S. Z. Gzhyc'kogo. - Scientific Messenger of Lviv National University of Veterinary Medicine and Biotechnologies. Series: Agricultural sciences, 19 (74): 182-187. doi:10.15421/nvlvet7440.

17. Yudin, V., Lyubimov, A., Nikitin, K., 2016. Selekcija cherno-pestroj porody krupnogo rogatogo skota s ispol'zovaniem razlichnyh metodov plemennogo podbora [Selection of black-and-white motley breed of cattle using different methods of breeding selection]. Izvestija Samarskoj gosudarstvennoj sel'skohozjajstvennoj akademii - Bulletin Samara State Agricultural Academy, 1: 37-40. DOI 10.12737/18326.

18. Hudson, C. D., Bradley, A. J., Breen, J. E., Green, M. J., 2012. Associations between udder health and reproductive performance in United Kingdom dairy cows. Journal of Dairy Science, 95 (7): 3683-3697.

19. Barth, A. D., Brito, L. F. C., Kastelic, J. P., 2008. The effect of nutrition on sexual development of bulls. Theriogenology, 70 (3): 485-494.

20. Ferri, C. P., Heins, B. J., Buckley, F., 2014. Crossbreeding in Dairy Cattle: Pros and Cons. WCDS Advances in Dairy Technology, 26: 223-243.

21. Gonzalez-Recio, O., Alenda, R., Chang, Y. M., Weigel, K. A., Gianola, D., 2006. Selection for female fertility using censored fertility traits and investigation of the relationship with milk production. Journal of Dairy Science, 89: 4438-4444.

\section{Fedorovych Ye., \\ Fedorovych $V$., \\ Mazur N., Bodnar P., \\ Fil S.}

Reproductive ability of cows and their descendants of different generations

Recently, there have been increasing reports in literary sources of the fact that reproductive performance of animals is determined by genetic factors, such as belonging to breed, type, genotype, lineage, parentage, method of selection etc. However, the impact of mothers on indicators of the reproductive capacity of their descendants of different generations has not yet been sufficiently studied. In view of the stated purpose of our research has been to study the reproductive capacity of cows and their descendants of different generations at highly productive herds (average milk yields for cow about $10000 \mathrm{~kg}$ ). The researches were carried out at herds of LLC "Veleten" of Sumy oblast and PJSC "Plemzavod " Stepnoy" of Zaporizhzhya oblast, created by absorption crossing of the cows of the Ukrainian Black-and-White dairy breed with Holstein breeders. Based on retrospective analysis of zootechnical accounting data (dairy management program herd of Uniform-Agri), and the results of our own researches on cows with calving 
period between 2004 and 2017: age and live weight at first productive insemination and first calving, duration of calving, period from calving to first insemination (Independence period), service-, dry and inter-calving periods, coefficient of reproductive capacity, calf output per 100 cows, conception rate and reproductive rate were studied. It is established that with each successive generation the age of the first productive insemination of heifers and the first calving of cows decreased, which caused a decrease in live weight of animals in these physiological periods. In both controlled herds, most of the studied features of reproductive ability between cows and their descendants of different generations had a significant difference, each successive generation of animals had better reproductive function than the previous one. In general, the descendants of different generations were noted with good reproduction capability and their ancestors with average, as indicated by this rate. Reproductive rate of descendants, depending on generation and lactation, was in the range of 47,8-52,1, and in the ancestors - in the range 40,2-43,6. Between the reproductive capacity of cows and their daughters, granddaughters and great-granddaughters weak connections of different directions were observed, which were mostly unreliable. Low relative variability of the studied features indicates a low level of inheritance of reproductive qualities of descendants.

Key words: cows, daughters, granddaughters, great-granddaughters, reproductive ability indices, correlation coefficients.

Дата надходження до редакції: 22.09.2019 р. 